\title{
Efficacy of Colchicine in Non-Hospitalized Patients with COVID-19
}

Jean-Claude Tardif, MD, Nadia Bouabdallaoui, MD, PhD, Philippe L. L’Allier, MD, Daniel Gaudet, MD, PhD, Binita Shah, MD, Michael H. Pillinger, MD, Jose Lopez-Sendon, MD, Protasio da Luz, MD, Lucie Verret, BPharm, DPH, MSc, Sylvia Audet, BPharm, MSc, MBA, Jocelyn Dupuis, MD, PhD, André Denault, MD, PhD, Martin Pelletier, PhD, Philippe A. Tessier, PhD, Sarah Samson, BSN, RN, Denis Fortin, BSN, RN, Jean-Daniel Tardif, BSc, David Busseuil, PhD, Elisabeth Goulet, RN, Chantal Lacoste, DEC, Anick Dubois, PhD, Avni Y. Joshi, MD, David D. Waters, MD, Priscilla Hsue, MD, Norman E. Lepor, MD, Frédéric Lesage, PhD, Nicolas Sainturet, PhD, Eve Roy-Clavel, MSc, Zohar Bassevitch, BSc, Andreas Orfanos, MBBS, Jean C. Grégoire, MD, Lambert Busque, MD, Christian Lavallée, MD, Pierre-Olivier Hétu, PhD, Jean-Sébastien Paquette, MD, MSc, Sylvie Levesque, MSc, Mariève Cossette, MSc, Anna Nozza, MSc, Malorie Chabot-Blanchet, MSc, Marie-Pierre Dubé, PhD, Marie-Claude Guertin, PhD, Guy Boivin, MD MSc, for the COLCORONA Investigators

From the Montreal Heart Institute, Université de Montréal (JCT, NB, PLL, LV, SA, JD, AD, SS, DF, JDT, DB, EG, CL, AD, FL, JCG, MPD); Ecogene-21 and Department of Medicine, Université de Montréal, Chicoutimi (DG); the New York University Grossman School of Medicine, New York (BS, MHP); H La Paz, IdiPaz, UAM, Ciber-CV Madrid, Spain (JLS); Instituto do Coração, Hospital das Clínicas, Faculdade de Medicina, Universidade de São Paulo, São Paulo, Brasil (PDL); Mayo Clinic, Rochester, Minnesota (AYJ); San Francisco General Hospital, California (DDW, PH); Cedars-Sinai Heart Institute, Geffen School of Medicine-UCLA (NEL); Hopital Maisonneuve-Rosemont, Université de Montréal (LB, CL); Centre Hospitalier de l’Université de Montréal (POH); Université Laval, Quebec City (JSP); Montreal Health Innovations Coordinating 
medRxiv preprint doi: https://doi.org/10.1101/2021.01.26.21250494; this version posted January 27, 2021. The copyright holder for this preprint (which was not certified by peer review) is the author/funder, who has granted medRxiv a license to display the preprint in perpetuity. It is made available under a CC-BY-NC 4.0 International license.

Center, Montreal (NS, ERC, ZB, AO, SL, MC, AN, MCB, MCG); Centre Hospitalier Universitaire de Québec and Université Laval (MP, PAT, GB).

Address correspondence to: Jean-Claude Tardif, MD, Montreal Heart Institute, 5000 Belanger street, Montreal, PQ, Canada H1T1C8; tel: 514-376-3330 (ext. 3604); email: jeanclaude.tardif@icm-mhi.org 


\begin{abstract}

\section{Background}

Evidence suggests the role of an inflammatory storm in COVID-19 complications. Colchicine is an orally administered, anti-inflammatory medication beneficial in gout, pericarditis and coronary disease.
\end{abstract}

\title{
Methods
}

We performed a randomized, double-blind trial involving non-hospitalized patients with COVID19 diagnosed by polymerase chain reaction (PCR) testing or clinical criteria. The patients were randomly assigned to receive colchicine ( $0.5 \mathrm{mg}$ twice daily for 3 days and once daily thereafter) or placebo for 30 days. The primary efficacy endpoint was the composite of death or hospitalization for COVID-19.

\section{Results}

A total of 4488 patients were enrolled. The primary endpoint occurred in $4.7 \%$ of the patients in the colchicine group and $5.8 \%$ of those in the placebo group (odds ratio, 0.79; $95.1 \%$ confidence interval (CI), 0.61 to 1.03; $\mathrm{P}=0.08$ ). Among the 4159 patients with PCR-confirmed COVID-19, the primary endpoint occurred in $4.6 \%$ and $6.0 \%$ of patients in the colchicine and placebo groups, respectively (odds ratio, 0.75; 95\% CI, 0.57 to 0.99; $\mathrm{P}=0.04$ ). In these patients with PCR-confirmed COVID-19, the odds ratios were 0.75 (95\% CI, 0.57 to 0.99) for hospitalization due to COVID-19, 0.50 (95\% CI, 0.23 to 1.07) for mechanical ventilation, and 0.56 (95\% CI, 0.19 to 1.66) for death. Serious adverse events were reported in $4.9 \%$ and $6.3 \%$ in the colchicine and placebo groups $(\mathrm{P}=0.05)$; pneumonia occurred in $2.9 \%$ and $4.1 \%$ of patients $(\mathrm{P}=0.02)$. Diarrhea was reported in $13.7 \%$ and $7.3 \%$ in the colchicine and placebo groups $(\mathrm{P}<0.0001)$. 
medRxiv preprint doi: https://doi.org/10.1101/2021.01.26.21250494; this version posted January 27, 2021. The copyright holder for this preprint (which was not certified by peer review) is the author/funder, who has granted medRxiv a license to display the preprint in perpetuity. It is made available under a CC-BY-NC 4.0 International license.

\section{Conclusion}

Among non-hospitalized patients with COVID-19, colchicine reduces the composite rate of death or hospitalization. (COLCORONA ClinicalTrials.gov number: NCT04322682) 
Accumulating evidence suggests that some patients with coronavirus disease 2019 (COVID-19) suffer from the cytokine storm syndrome. ${ }^{1}$ Treatment of this exaggerated inflammatory response has been advocated to address the immediate need to reduce the risk of complications. ${ }^{1,2}$ The steroid dexamethasone reduces mortality in patients hospitalized with COVID-19, but only if they receive mechanical ventilation or supplemental oxygen. ${ }^{3}$ In addition, the anti-interleukin-6 receptor antibody tocilizumab was shown to reduce the likelihood of progression to mechanical ventilation in patients hospitalized for COVID-19 pneumonia. $^{4}$

The severe acute respiratory syndrome coronavirus 1 (SARS-CoV-1), which is closely related to the SARS-CoV-2 virus responsible for COVID-19, has been shown to activate the NLRP3 inflammasome. ${ }^{5}$ This intracellular complex activates several interleukins, which then trigger an inflammatory cascade. Given that elevated levels of interleukin-6 are associated with adverse clinical outcomes in COVID-19, ${ }^{6}$ targeting the NLRP3 inflammasome may reduce related complications in patients at risk of cytokine activation.

Prevention of COVID-19 complications in an out-patient setting ideally requires a clinically available, orally administered and inexpensive medication targeting the inflammasome with a known favorable safety and tolerability profile. Colchicine is a potent anti-inflammatory agent used to treat gout, viral pericarditis, coronary disease and familial Mediterranean fever. ${ }^{7-10}$ Its mechanism of action is through the inhibition of tubulin polymerization, with effects on the inflammasome, cellular adhesion molecules and inflammatory chemokines. ${ }^{11-13}$ In an experimental model of acute respiratory distress syndrome, colchicine was shown to reduce inflammatory lung injury and respiratory failure by interfering with leukocyte activation and recruitment. ${ }^{14}$ 
We conducted the COLchicine CORONAvirus SARS-CoV-2 (COLCORONA) trial in nonhospitalized patients with COVID-19 to evaluate the effects of colchicine on complications including hospitalization and death and its safety and tolerability

\section{METHODS}

\section{TRIAL DESIGN}

COLCORONA was a randomized, double-blind, placebo-controlled, investigator-initiated trial comparing colchicine (0.5 mg twice daily for the first 3 days and then once daily for 27 days thereafter) with placebo in a 1:1 ratio. The study was funded by the Government of Quebec, the Bill and Melinda Gates Foundation, the National Institutes of Health and philanthropist Sophie Desmarais. The trial protocol, available with the full text of this article at XX.org, was designed by the study steering committee. The protocol was approved by the institutional review board at all centers involved in the 6 countries that participated in the trial (Supplementary Appendix). All study support activities, including project coordination, data management, site monitoring, and statistical oversight and analyses, were performed at the Montreal Health Innovations Coordinating Center (MHICC). The trial was overseen by a data safety monitoring board of independent experts. The study medication and matching placebo were provided by Pharmascience (Montreal), which had no role in the design or conduct of the trial or the preparation or review of the manuscript. The first author (JCT) and lead statistician (MCG) prepared the first draft of the manuscript, had full access to the trial database, generated statistical analyses, made the decision to submit the manuscript for publication, and assume responsibility for the accuracy and completeness of the data and analyses and for the fidelity to the protocol. 
medRxiv preprint doi: https://doi.org/10.1101/2021.01.26.21250494; this version posted January 27, 2021. The copyright holder for this preprint (which was not certified by peer review) is the author/funder, who has granted medRxiv a license to display the preprint in perpetuity.

It is made available under a CC-BY-NC 4.0 International license .

\section{TRIAL POPULATION}

Patients were eligible if they were at least 40 years of age, had received a diagnosis of COVID-19 within 24 hours of enrollment, were not currently hospitalized and not under immediate consideration for hospitalization, and presented at least one of the following high-risk criteria: age of 70 years or older, obesity (body-mass index of $30 \mathrm{~kg} / \mathrm{m}^{2}$ or more), diabetes, uncontrolled hypertension (systolic blood pressure $\geq 150 \mathrm{~mm} \mathrm{Hg}$ ), known respiratory disease, known heart failure, known coronary disease, fever of at least $38.4^{\circ} \mathrm{C}$ within the last 48 hours, dyspnea at the time of presentation, bicytopenia, pancytopenia, or the combination of high neutrophil and low lymphocyte counts. The diagnosis of COVID-19 was made by local laboratories using polymerase chain reaction testing on a naso-pharyngeal swab specimen. Given the restrictions in laboratory testing early in the pandemic, a diagnosis was also accepted as an epidemiological link with a household member who had a positive nasopharyngeal test result for patients with symptoms compatible with COVID-19, or by a clinical algorithm in a symptomatic patient without an obvious alternative cause as per official guidelines (Supplementary Table S1). ${ }^{15}$ Women were either not of childbearing potential or practicing adequate contraception.

Patients were excluded if they had inflammatory bowel disease, chronic diarrhea or malabsorption; pre-existent progressive neuromuscular disease; estimated glomerular filtration rate less than $30 \mathrm{ml} / \mathrm{minute} / 1.73 \mathrm{~m}^{2}$; severe liver disease; current treatment with colchicine; current chemotherapy for cancer; or a history of significant sensitivity to colchicine. Further details regarding eligibility criteria are provided in the Supplementary Appendix.

Written informed consent was obtained electronically or on paper from all patients before enrollment following a telemedicine or in-person visit, respectively. Study medication was delivered at the patient's house within 4 hours of enrollment. Clinical evaluations occurred by telephone at 15 and 30 days following randomization. 


\section{ENDPOINTS}

The primary efficacy endpoint was a composite of death or hospitalization due to COVID-19 infection in the 30 days following randomization. The secondary endpoints consisted of the components of the composite primary endpoint; and the need for mechanical ventilation in the 30 days following randomization. Pneumonias, other serious adverse events, and non-serious adverse events were also collected.

\section{STATISTICAL ANALYSES}

It was estimated that a sample size of approximately 6000 randomized patients with 3000 patients in each treatment group would be required to detect a $25 \%$ relative risk reduction with colchicine with a power of $80 \%$ given a primary endpoint event rate of $7 \%$ in the placebo group and a twosided test at the 0.05 significance level.

The efficacy analyses were conducted according to the intention-to-treat principle. The primary endpoint was compared between the two treatment groups using a chi-square test and the odds ratio along with 95.1\% confidence interval, was provided. Secondary endpoints were analyzed similarly. Because of potential limitations to the specificity of COVID-19 diagnosis made on clinical or epidemiological criteria alone, a pre-specified analysis included only those patients who were enrolled based on a positive polymerase chain reaction test. Pre-specified subgroup analyses were conducted using logistic regression models including the treatment group, the subgroup factor and the treatment $\mathrm{x}$ subgroup factor interaction.

Interim analyses were planned after 25, 50 and $75 \%$ of the primary endpoint events had occurred. The pre-specified stopping rule for efficacy was based on the Lan-DeMets procedure with the O’Brien-Fleming alpha-spending function. Following its review of the first two interim 
medRxiv preprint doi: https://doi.org/10.1101/2021.01.26.21250494; this version posted January 27, 2021. The copyright holder for this preprint (which was not certified by peer review) is the author/funder, who has granted medRxiv a license to display the preprint in perpetuity.

It is made available under a CC-BY-NC 4.0 International license .

results, the monitoring board recommended that the trial should continue as planned. On December 11, 2020, the steering committee chairman informed the data safety monitoring board that the investigators had decided to terminate the study once $75 \%$ of the planned patients were recruited and had completed the 30-day follow-up. This decision was made due to logistical issues related to maintaining the central study call center active 24 hours per day for a prolonged period of time, as well as the need to provide healthcare systems with study results in a timely fashion given the state of the COVID-19 pandemic. To account for the interim analyses, the statistical significance level was set to 0.0490 for the final analysis of the primary endpoint. All other statistical tests were two-sided and conducted at the 0.05 significance level.

Statistical analyses were performed using SAS version 9.4. There was no prespecified plan to adjust for multiple comparisons across the multiple methods used to analyze the primary outcome and secondary endpoints; results of these analyses are reported with point estimates and 95\% CI, without P-values. 95\% CIs are not adjusted for multiple comparisons and inferences drawn from them may not be reproducible. The statistical analysis plan was approved on November 25, 2020.

\section{RESULTS}

\section{PATIENTS}

Trial enrollment began in March 2020 and was completed in December 2020; the last trial visit was in January 2021. A total of 4488 patients underwent randomization and were followed for 30 days. At the time of database lock and unblinding on January 20, 2021, vital and primary endpoint event status were available for all except for 93 patients (97.9\%). Details regarding the disposition of the patients are provided in Figure 1.

The baseline characteristics of patients are shown in Table 1. Patients were enrolled a mean of 5.3 days after the onset of COVID-19 symptoms. The mean age of participants was 54.7 years, 
$53.9 \%$ of the patients were women, mean body-mass index was $30.0 \mathrm{~kg} / \mathrm{m}^{2}$, and $19.9 \%$ had diabetes. The mean treatment duration with the trial medication was 26.2 days.

\section{CLINICAL EFFICACY ENDPOINTS}

A primary endpoint event occurred in $4.7 \%$ of the patients in the colchicine group, as compared with $5.8 \%$ of the patients in the placebo group (odds ratio, $0.79 ; 95.1 \%$ confidence interval [CI], 0.61 to $1.03 ; \mathrm{P}=0.08$ ). Table 2 shows the event rates and odds ratios for the components of the primary endpoint, which included death (odds ratio, 0.56; 95\% CI, 0.19 to 1.67) and hospitalization due to COVID-19 (odds ratio, 0.79; 95\% CI, 0.60 to 1.03), as well as for the secondary efficacy endpoint of the need for mechanical ventilation (odds ratio, 0.53; 95\% CI, 0.25 to 1.09).

In the pre-specified analysis of the 4159 patients with COVID-19 confirmed by a polymerase chain reaction test, the rates of the primary endpoint were $4.6 \%$ and $6.0 \%$ in the colchicine and placebo groups, respectively (odds ratio, 0.75; 95\% CI, 0.57 to 0.99; $\mathrm{P}=0.04$ ). Among these patients with confirmed COVID-19, the odds ratios were 0.75 (95\% CI, 0.57 to 0.99) for hospitalization due to the infection and 0.56 (95\% CI, 0.19 to 1.66) for death. The secondary efficacy endpoint of the need for mechanical ventilation occurred in $0.5 \%$ of the patients in the colchicine group, as compared with $1.0 \%$ of the patients in the placebo group (odds ratio, 0.50; 95\% CI, 0.23 to 1.07).

Efficacy results in prespecified subgroups are shown in Table 3. Among the patients with diabetes, the primary endpoint occurred in $6.1 \%$ of those in the colchicine group and $9.6 \%$ in the placebo group (odds ratio, $0.61 ; 95 \%$ CI, 0.37 to 1.01 ).

\section{SAFETY AND ADVERSE EVENTS}

The rates of serious adverse events were $4.9 \%$ in the colchicine group and $6.3 \%$ in the placebo group $(\mathrm{P}=0.05)$, and pneumonia occurred in $2.9 \%$ and $4.1 \%$ of the patients in the two groups 
medRxiv preprint doi: https://doi.org/10.1101/2021.01.26.21250494; this version posted January 27, 2021. The copyright holder for this preprint (which was not certified by peer review) is the author/funder, who has granted medRxiv a license to display the preprint in perpetuity.

It is made available under a CC-BY-NC 4.0 International license .

$(\mathrm{P}=0.02)$. Pulmonary embolism was diagnosed in $0.5 \%$ of the patients in the colchicine group and $0.1 \%$ of those in the placebo group (0.01). The rates of adverse events that were considered related to trial medication were $24.2 \%$ and $15.5 \%$ (Table 4 ). At least one treatment-emergent gastrointestinal adverse event occurred in $23.9 \%$ of the patients in the colchicine group, as compared with $14.8 \%$ of the patients in the placebo group. Diarrhea was reported in $13.7 \%$ and $7.3 \%$ of patients in the two trial groups $(\mathrm{P}<0.0001)$.

\section{DISCUSSION}

In COLCORONA, the risk of the primary composite efficacy endpoint of death or hospitalization due to COVID-19 infection in the 30 days following randomization, was lower among the patients who were randomly assigned to receive colchicine than among those who received placebo. Because of the shortage of reagents for polymerase chain reaction tests and the restriction in the use of such testing early in the pandemic, diagnosis of probable COVID-19 through an epidemiological link or compatible symptoms was initially allowed in the study. When the 93\% of patients who had a formal diagnosis of COVID-19 are considered, the benefit of colchicine on the primary efficacy endpoint was more marked (25\%) and statistically significant. Treatment with colchicine was associated with concordant effects on hospitalizations, use of mechanical ventilation and deaths in patients with a diagnosis of COVID-19 confirmed by polymerase chain reaction testing.

The effect of colchicine on the primary endpoint was consistent across subgroups of patients based on various clinical characteristics. Although the benefits of colchicine appeared to be more marked in patients with diabetes and men, there was no significant heterogeneity in the results. Because the event rates were higher in patients with these characteristics, the effect of colchicine might have been more readily detectable. Diabetes is a pro-inflammatory state, which might 
explain the greater risk of complications of COVID-19 in patients afflicted by that disease. Despite the link between weight, insulin resistance and type 2 diabetes, the effects of colchicine did not differ whether the body-mass index was above or below $30 \mathrm{~kg}$ per square meter. In contrast, there is no readily obvious basis for a sex-related difference in responses to colchicine. Of note, the concomitant use of an inhibitor of the renin-angiotensin system did not appear to modify the clinical response to colchicine.

The most common adverse events observed were gastro-intestinal. Diarrhea was reported by $13.7 \%$ and $7.3 \%$ of patients in the colchicine and placebo groups, respectively. The number of patients with any serious adverse event was smaller in the colchicine group compared to placebo (4.9\% versus 6.3\%). Pneumonia was reported less frequently in patients of the colchicine group (2.9\%) than those of the placebo group (4.1\%). Colchicine has previously been shown to reduce acute lung injury in an experimental model of acute respiratory distress syndrome. ${ }^{14}$ The risk of viral inflammatory pneumonitis might therefore be lowered by colchicine in patients with COVID19. In contrast, there was no evidence of an increased risk of bacterial pneumonia in COLCORONA. The number of reported cases of pulmonary embolism was higher in patients of the colchicine group compared to placebo (11 versus 2). Whether this represents a real phenomenon or simply the play of chance is not known. Colchicine has previously been shown in murine models to lower the release of alpha-defensin associated with large thrombus burdens and in clinical studies to reduce the aggregation between neutrophils and platelets. ${ }^{16-18}$ Nevertheless, the numbers of hospitalizations, use of mechanical ventilation and deaths were lower in the colchicine group than in the placebo group. Although uncommon, the number of reports of cutaneous rash was lower with colchicine than in the placebo group (4 versus 13). 
Our trial has certain limitations. The study was stopped when $75 \%$ of the planned patients were recruited and had completed the 30-day follow-up. In addition to the logistical issues faced in the current challenging context, the perceived need to disseminate the study results rapidly in view of the current state of the pandemic largely contributed to our decision. The duration of follow-up was relatively short at approximately 30 days. The evolution of persistent COVID-19 symptoms and the effects of longer-term treatment with colchicine were not evaluated. The benefit of a shorter course of colchicine therapy for less than 30 days is also not entirely known, although the results of a small open-label study showed benefits of treatment administered for up to 3 weeks. ${ }^{19}$ Finally, our results apply to patients who have a proven diagnosis of COVID-19, are at risk of clinical complications and are not hospitalized at the time of treatment initiation.

In conclusion, among non-hospitalized patients with confirmed COVID-19, colchicine led to a lower rate of the composite of death or hospitalization than placebo. 


\section{References}

1. Faigenbaum DC, June CH. Cytokine storm. N Engl J Med 2020;383:2255-73.

2. Fedson DS. Treating the host response: an alternative way to manage Ebola in Africa and the next influenza pandemic. J Glob Health 2019;9:010322. doi: 10.7189/jogh.09.010322.

3. The RECOVERY collaborative group. Dexamethasone in hospitalized patients with Covid-19 Preliminary report. N Engl J Med 2020 Jul 17:NEJMoa2021436. doi: 10.1056/NEJMoa2021436. (online ahead of print). PMID: 32678530.

4. Salama C, Han J, Yau L, et al. Tocilizumab in patients hospitalized with Covid-19 pneumonia. N Engl J Med 2021;384:20-30.

5. Nieto-Torres JL, Verdiá-Báguena C, Jimenez-Guardeno JM, et al. Severe acute respiratory syndrome coronavirus E protein transports calcium ions and activates the NLRP3 inflammasome. Virology 2015;485:330-9.

6. Coomes EA, Haghbayan H. Interleukin-6 in Covid-19 : A systematic review and meta-analysis. Rev Med Virol 2020;30(6):1-9.

7. Imazio M, Bobbio M, Cecchia E, et al. Colchicine in addition to conventional therapy for acute pericarditis: results of the COlchicine for acute PEricarditis (COPE) trial. Circulation 2005;112:2012-6.

8. Tardif JC, Kouz S, Waters DD, et al. Efficacy and safety of low-dose colchicine after myocardial infarction. N Engl J Med 2019;381:2497-505.

9. Nidorf SM, Fiolet ATL, Mosterd A, et al. Colchicine in patients with chronic coronary disease. N Engl J Med 2020;383:1831-47.

10.Cerquaglia C, Diaco M, Nucera G, La Regina M, Montalto M, Manna R. Pharmacological and clinical basis of treatment of familial Mediterranean fever (FMF) with colchicine or analogues: an update. Curr Drug Targ Inflamm Allergy 2005;4:117-24. 
11. Ravelli RBG, Gigant B, Curmi PA, et al. Insight into tubulin regulation from a complex with colchicine and a stathmin-like domain. Nature 2004;428:198-202.

12. Pope RM, Tschopp J. The role of interleukin-1 and the inflammasome in gout: implications for therapy. Arthritis Rheumat 2007;56:3183-8.

13. Perico N. Ostermann D, Bontempeill M, et al. Colchicine interferes with L-selectin and leukocyte function associated antigen-1 expression on human $\mathrm{T}$ lymphocytes and inhibits $\mathrm{T}$ cell activation. J Am Soc Nephrol 1996;7:594-601.

14. Dupuis J, Sirois MG, Rhéaume E, et al. Colchicine reduces lung injury in experimental acute respiratory distress syndrome. PLoS One 2020;15:e0242318. doi: 10.1371/journal.pone.0242318. eCollection 2020.PMID: 33264297.

15. European Centre for Disease Preventionn and Control. Case definition for coronavirus disease 2019 (COVID-19). https://www.ecdc.europa.eu/en/covid-19/surveillance/case-definition

16. Abu-Fanne R, Stepanova V, Litvinov RI, et al. Neutrophil defensins promote thrombosis in vivo by altering fibrin formation, structure, and stability. Blood 2019;133:481-93.

17. Leichman AK. Hadassah researchers pinpoint source of corona blood clots. ISRAEL21c (internet), 2020. Available: https://www.israel21c.org/hadassah-researchers-find- source-ofcorona-blood-clots/ (accessed on 25 August 2020).

18. Shah B, Allen N, Harchandani B, et al. Effect of colchicine on platelet-platelet and plateletleukocyte interactions: a pilot study in healthy subjects. Inflammation 2016;39:182-9.c

19. Deftereos SG, Giannopoulos G, Vrachatis DA, et al. Effect of colchicine vs standard care on cardiac and inflammatory biomarkers and clinical outcomes in patients hospitalized with coronavirus disease 2019 -The GRECCO-19 randomized clinical trial. JAMA Network Open 2020 
Table 1. Characteristics of the Trial Patients.

\begin{tabular}{lcc}
\hline Characteristic & Colchicine (N=2235) & Placebo (N=2253) \\
\hline Age - years & $54.4 \pm 9.7$ & $54.9 \pm 9.9$ \\
Female sex - no. (\%) & $1238(55.4 \%)$ & $1183(52.5 \%)$ \\
Caucasian - no. (\%) & $2086(93.3 \%)$ & $2096(93.2 \%)$ \\
Body-mass index (kg/m²) & $30.0 \pm 6.2$ & $212(9.4 \%)$ \\
Smoking - no. (\%) & $217(9.7 \%)$ & $848(37.6 \%)$ \\
Hypertension - no. (\%) & $781(34.9 \%)$ & $450(20.0 \%)$ \\
Diabetes - no. (\%) & $444(19.9 \%)$ & $605(26.9 \%)$ \\
Respiratory disease - no. (\%) & $583(26.1 \%)$ & $72(3.2 \%)$ \\
Prior MI - no. (\%) & $65(2.9 \%)$ & $18(0.8 \%)$ \\
Prior heart failure - no. (\%) & $24(1.1 \%)$ & \\
\hline
\end{tabular}

MI denotes myocardial infarction. 
medRxiv preprint doi: https://doi.org/10.1101/2021.01.26.21250494; this version posted January 27, 2021. The copyright holder for this preprint (which was not certified by peer review) is the author/funder, who has granted medRxiv a license to display the preprint in perpetuity.

It is made available under a CC-BY-NC 4.0 International license .

Table 2. Rates and Odds Ratios for Major Clinical Outcomes.

\begin{tabular}{lccc}
\hline Clinical Outcome & Colchicine & Placebo & Odds Ratio \\
& & P Value \\
& & & \\
\hline
\end{tabular}

\begin{tabular}{lll}
\hline ITT population & $\mathrm{N}=2235$ & $\mathrm{~N}=2253$
\end{tabular}

Primary composite endpoint - no. (\%) $104(4.7 \%) \quad 131(5.8 \%) \quad 0.79(0.61-1.03) \quad 0.08$

Components of primary endpoint:

Death - no. (\%) $\quad 5(0.2 \%) \quad 9(0.4 \%) \quad 0.56(0.19-1.67)$

Hospitalization for COVID-19 no. (\%) 101 (4.5\%) 128 (5.7\%) $\quad 0.79(0.60-1.03)$

Secondary endpoint:

Mechanical ventilation - no. (\%)

$11(0.5 \%) \quad 21(0.9 \%) \quad 0.53(0.25-1.09)$

Patients with PCR-proven COVID-19 $\quad$ N=2075 N=2084

$\begin{array}{lllll}\text { Primary composite endpoint }- \text { no. }(\%) & 96(4.6 \%) & 126(6.0 \%) & 0.75(0.57-0.99) & 0.04\end{array}$

Components of primary endpoint:

Death - no. (\%) $\quad 5(0.2 \%) \quad 9(0.4 \%) \quad 0.56(0.19-1.66)$

Hospitalization for COVID-19 no. (\%) 93 (4.5\%) $123(5.9 \%) \quad 0.75(0.57-0.99)$

Secondary endpoint:

Mechanical ventilation - no. (\%) $\quad 10(0.5 \%) \quad 20(1.0 \%) \quad 0.50(0.23-1.07)$

ITT denotes Intention-to-Treat. 
medRxiv preprint doi: https://doi.org/10.1101/2021.01.26.21250494; this version posted January 27, 2021. The copyright holder for this preprint (which was not certified by peer review) is the author/funder, who has granted medRxiv a license to display the preprint in perpetuity.

It is made available under a CC-BY-NC 4.0 International license .

Table 3. Primary Efficacy Composite Endpoint in Prespecified Subgroups.

\section{Subgroup \\ History of diabetes}

\section{Colchicine}

Placebo
Odds ratio

(95\% CI)

no. of patients with event/total no. of patients (\%)

Yes

No

History of hypertension

Yes

No

Smoking

Non-smoker

Previous smoker

Active smoker

Age

$$
\begin{aligned}
& \geq 70 \text { years } \\
& <70 \text { years }
\end{aligned}
$$

Sex

Men

Women

Body-mass index

$$
\begin{aligned}
& \geq 30 \mathrm{~kg} / \mathrm{m}^{2} \\
& <30 \mathrm{~kg} / \mathrm{m}^{2}
\end{aligned}
$$

Respiratory disease

Yes

No

Cardiovascular disease

Yes

No

Use of ACEi/ARB

$\begin{array}{ccc}27 / 444(6.1 \%) & 43 / 450(9.6 \%) & 0.61(0.37-1.01) \\ 77 / 1791(4.3 \%) & 88 / 1803(4.9 \%) & 0.88(0.64-1.20)\end{array}$

48/781 (6.1\%)

64/848 (7.5\%)

0.80 (0.54-1.18)

56/1454 (3.9\%)

67/1405 (4.8\%)

$0.80(0.56-1.15)$

59/1279 (4.6\%)

71/1270 (5.6\%)

0.82 (0.57-1.16)

38/738 (5.1\%)

56/770 (7.3\%)

0.69 (0.45-1.06)

7/217 (3.2\%)

4/212 (1.9\%)

$1.73(0.50-6.01)$

18/190 (9.5\%) 27/213 (12.7\%)

$0.72(0.38-1.36)$

86/2045 (4.2\%) 104/2040 (5.1\%)

$0.82(0.61-1.09)$

58/997 (5.8\%)

90/1070 (8.4\%)

0.67 (0.48-0.95)

46/1238 (3.7\%)

41/1183 (3.5\%)

$1.07(0.70-1.65)$

53/1012 (5.2\%)

$70 / 1040(6.7 \%)$

$0.77(0.53-1.11)$

$50 / 1216(4.1 \%)$

61/1205 (5.1\%)

$0.80(0.55-1.18)$

35/583 (6.0\%)

48/605 (7.9\%)

$0.74(0.47-1.16)$

69/1652 (4.2\%)

83/1647 (5.0\%)

$0.82(0.59-1.14)$

$$
\text { 6/119 (5.0\%) }
$$

$11 / 122(9.0 \%)$

$0.54(0.19-1.50)$

98/2116 (4.6\%) 120/2131 (5.6\%)

$0.81(0.62-1.07)$ 
medRxiv preprint doi: https://doi.org/10.1101/2021.01.26.21250494; this version posted January 27, 2021. The copyright holder for this preprint (which was not certified by peer review) is the author/funder, who has granted medRxiv a license to display the preprint in perpetuity. It is made available under a CC-BY-NC 4.0 International license.

\begin{tabular}{cccc}
\hline Yes & $37 / 602(6.1 \%)$ & $53 / 676(7.8 \%)$ & $0.77(0.50-1.19)$ \\
No & $67 / 1633(4.1 \%)$ & $78 / 1577(4.9 \%)$ & $0.82(0.59-1.15)$ \\
\hline
\end{tabular}

ACEi denotes angiotensin-converting enzyme inhibitor, and ARB angiotensin-receptor blocker. 
medRxiv preprint doi: https://doi.org/10.1101/2021.01.26.21250494; this version posted January 27, 2021. The copyright holder for this preprint

(which was not certified by peer review) is the author/funder, who has granted medRxiv a license to display the preprint in perpetuity.

It is made available under a CC-BY-NC 4.0 International license .

Table 4. Proportions of Patients with Adverse Events in the Safety Population $\dagger$.

\begin{tabular}{lccc}
\hline Adverse event & Colchicine (N=2195) & Placebo (N=2217) & P Value* \\
\hline Any SAE - no. (\%) & $108(4.9 \%)$ & $139(6.3 \%)$ & 0.05 \\
Pneumonia SAE - no. (\%) & $63(2.9 \%)$ & $92(4.1 \%)$ & 0.02 \\
Pulmonary embolism - no. (\%) & $11(0.5 \%)$ & $2(0.1 \%)$ & 0.01 \\
Any related AE - no. (\%) & $532(24.2 \%)$ & $344(15.5 \%)$ & $<0.0001$ \\
Gastro-intestinal AE - no. (\%) & $524(23.9 \%)$ & $328(14.8 \%)$ & $<0.0001$ \\
Gastro-intestinal SAE - no. (\%) & $6(0.3 \%)$ & $3(0.1 \%)$ & 0.31 \\
Diarrhea AE - no. (\%) & $300(13.7 \%)$ & $161(7.3 \%)$ & $<0.0001$ \\
Nausea AE - no. (\%) & $43(2.0 \%)$ & $47(2.1 \%)$ & 0.71 \\
GI haemorrhage AE - no. (\%) & $1(0.0 \%)$ & $0(0 \%)$ & 0.33 \\
Rash AE - no. (\%) & $4(0.2 \%)$ & $13(0.6 \%)$ & 0.03 \\
\hline
\end{tabular}

AE denotes adverse event; GI, gastro-intestinal; and SAE, serious adverse event.

†The safety population refers to the patients who took at least one dose of trial medication. 
medRxiv preprint doi: https://doi.org/10.1101/2021.01.26.21250494; this version posted January 27, 2021. The copyright holder for this preprint (which was not certified by peer review) is the author/funder, who has granted medRxiv a license to display the preprint in perpetuity. It is made available under a CC-BY-NC 4.0 International license.

Figure Legends

Figure 1. Consort Diagram of the Flow of Patients During the Trial. 


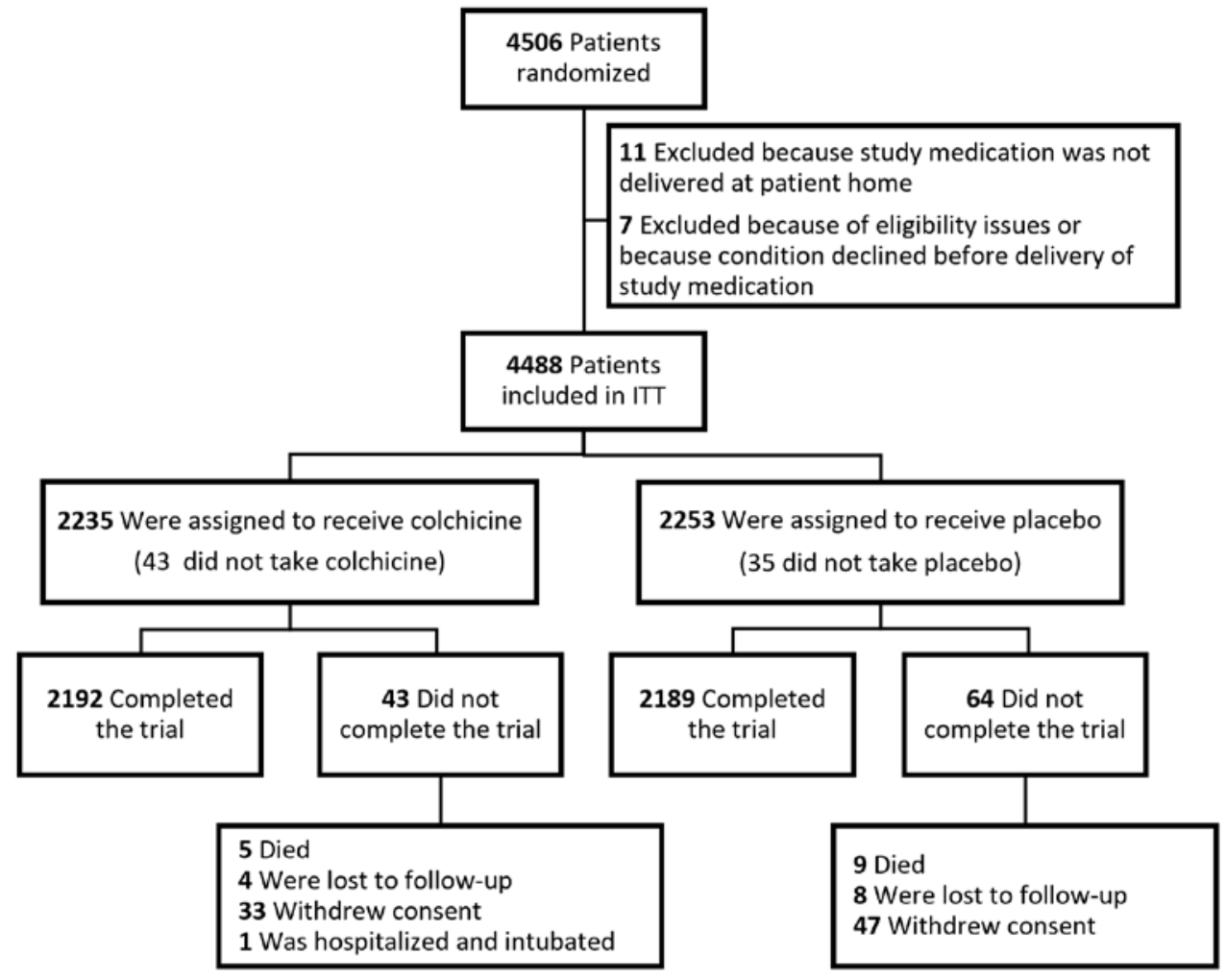

